\title{
Influence of acute kidney injury on high sensitive troponin after cardiac surgery. a single center retrospective observational study
}

\author{
AS Omar ${ }^{1,2^{*}}$, P Sivadasan ${ }^{1}$, S Hanoura ${ }^{1,3}$, S Sudarsanan ${ }^{1}$, Y Shouman ${ }^{1}$, H Ragab ${ }^{1,3}$, AK Tuli $^{1}$, R Singh ${ }^{4}$, A Al Khulaifi ${ }^{1}$ \\ From ESICM LIVES 2015 \\ Berlin, Germany. 3-7 October 2015
}

\begin{abstract}
Introduction
The risk assessment of cardiac troponin and other cardiac biomarkers in end-stage renal disease is not equivalent where clinical decision making in patients with renal diseases based on cardiac biomarkers needs justification in relation to patient management or outcomes [1]. Long-term outcome could be influenced by acute kidney injury (AKI) in cardiac surgery [2], but cardiac troponins need exploration in theses settings.
\end{abstract}

\section{Objectives}

Assess the diagnostic performance of high sensitive troponin $\mathrm{T}$ (hsTnT) in the settings of cardiac surgery-induced AKI. Link it with mortality as well as the lengths of ventilation, ICU stay and hospital stay.

\section{Methods}

Single center observational retrospective study. A database was available for all patients (sex, age, body mass index, duration of the operation, duration of ICU and hospital length of stay, levels of cardiac enzymes, evidence of perioperative myocardial infarction, early mortality. The lengths of ventilation, stay in ICU, and hospitalization. Based on the Acute Kidney Injury Network, AKI was defined as an abrupt (within $48 \mathrm{~h}$ ) reduction in kidney function, defined as an absolute increase in serum creatinine concentration of $0.3 \mathrm{mg} / \mathrm{dL}(26.4 \mu \mathrm{mol} / \mathrm{L})$ or greater or a percentage increase of $50 \%$ or greater (1.5-fold from baseline). Patients divided into 2 groups, group I without AKI (259 patients) and group II with AKI (100 patients) where serial of hsTnT and creatine kinase (CK)-MB followed.

${ }^{1}$ Hamad Medical Corporation, Cardiothoracic Surgery-Heart Hospital, Doha, Qatar

Full list of author information is available at the end of the article
Both groups compared and statistically analyzed. We enrolled 359 patients, patients with ESRD were excluded.

\section{Results}

The mean age in our study population was $55.1 \pm 10.2$ years. High association of AKI (27.8\%) was found in our patients. Both groups were matched regarding the age, gender, body mass index, the association of diabetes or hypertension, and Euro score. AKI group had significantly higher mortality $6 \%$ vs group I $1.7 \%(p=0.026)$. The hsTnT significant changes between both groups remain all over the course, which unparalleled to those of CK-MB (Figures 1\&2). The AKI group with more associated with heart failure $17.9 \%$ vs $4.9 \%(\mathrm{p}=.000)$; and post-operative atrial fibrillation, $12.4 \%$ vs $2.9 \%$ ( $\mathrm{p}=$ 0.005). Lengths of ventilation, stays in ICU and in hospital were significantly higher in the AKI group (Table 1).

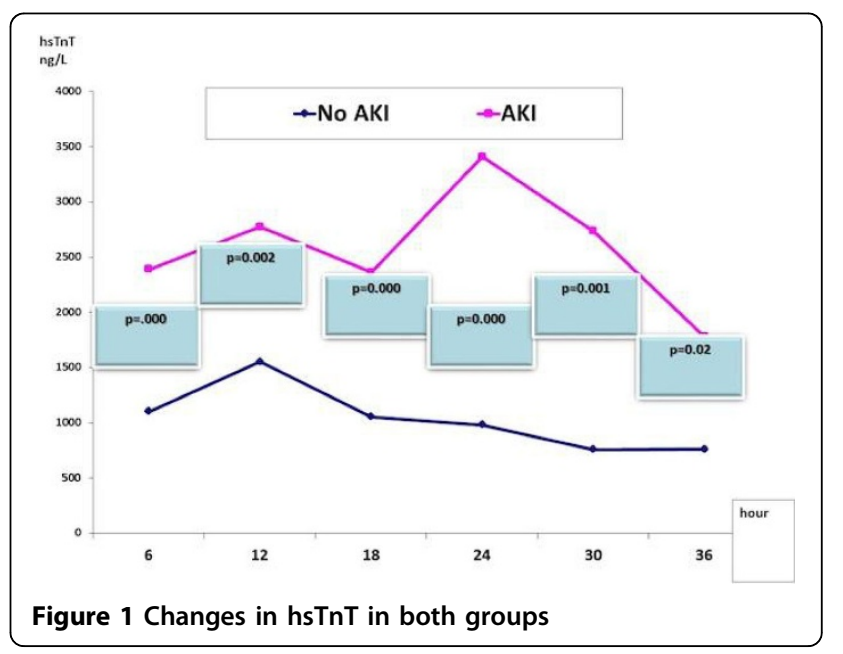

C 2015 Omar et al.; This is an Open Access article distributed under the terms of the Creative Commons Attribution License (http:// creativecommons.org/licenses/by/4.0), which permits unrestricted use, distribution, and reproduction in any medium, provided the original work is properly cited. 


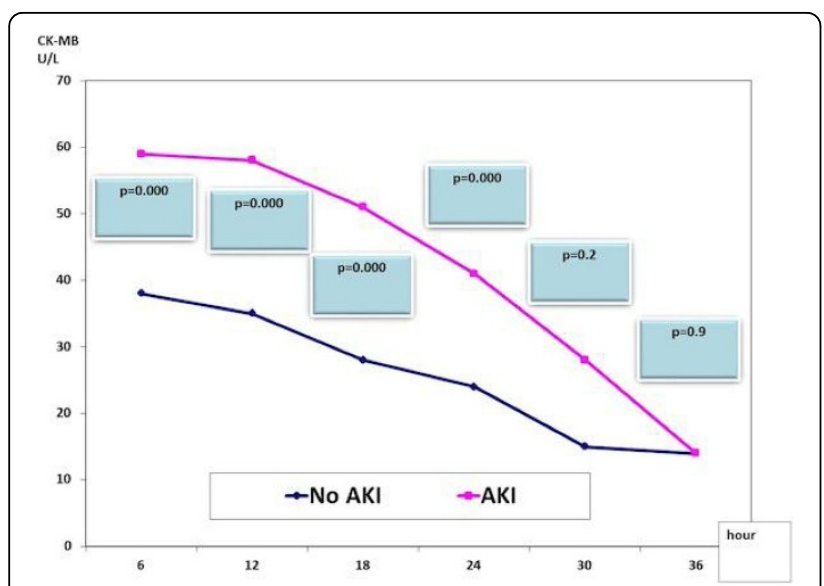

Figure 2 Changes in CK-MB in both groups

\section{References}

1. Vesely DL: Natriuretic peptides and acute renal failure. Am J PhysiologyRenal Physiology 2003, 285(2):F167-F177.

2. Prowle JR, Kirwan CJ: Acute Kidney Injury After Cardiac Surgery: The Injury That Keeps on Hurting?*. Critical Care Med 2014, 42(9):2142-2143.

doi:10.1186/2197-425X-3-S1-A633

Cite this article as: Omar et al:: Influence of acute kidney injury on high sensitive troponin after cardiac surgery. a single center retrospective observational study. Intensive Care Medicine Experimental 2015 3(Suppl 1): A633.

Table 1 Comparison between both groups.

\begin{tabular}{|c|c|c|c|}
\hline Variable & $\begin{array}{l}\text { Group I (No AKI) } \\
259(\%)\end{array}$ & $\begin{array}{l}\text { Group II (AKI) } \\
100(\%)\end{array}$ & P- Value \\
\hline Age & $54.43 \pm 10.8$ & $56.09 \pm 10.7$ & 0.13 \\
\hline Diabetes & $138(53.2)$ & $56(56)$ & 0.38 \\
\hline Euro score & $3.8 \pm 2.4$ & $5.1 \pm 3.6$ & 0.06 \\
\hline POAF & $7(2.7)$ & $12(12)$ & 0.005 \\
\hline Mortality & $5(1.9)$ & $7(7)$ & 0.026 \\
\hline $\begin{array}{l}\text { LOV } \\
\text { (minutes) }\end{array}$ & $364.1 \pm 112$ & $575.5 \pm 199$ & 0.001 \\
\hline $\begin{array}{l}\text { LOSICU } \\
\text { (hours) }\end{array}$ & $52.9 \pm 41.1$ & $109.4 \pm 89$ & 0.000 \\
\hline LOH (days) & $10.8 \pm 6.4$ & $15.8 \pm 7.3$ & 0.007 \\
\hline
\end{tabular}

POAF: post operative atrial fibrillation, LOSICU length of stay in ICU, LOV length of ventilation, $\mathrm{LOH}$ hospital length of stay

\section{Conclusions}

Unlike the CK-MB profile, the hsTnT showed significant changes between both groups all over the course denoting possible delayed clearance in patients with AKI that needs to put in consideration in interpreting post-operative myocardial injury and infarction in this population.

\section{Grant Acknowledgment}

All members of CT department and medical research center, HMC, Doha, Qatar

\section{Authors' details}

${ }^{1}$ Hamad Medical Corporation, Cardiothoracic Surgery-Heart Hospital, Doha, Qatar. ${ }^{2}$ Faculty of Medicine, Beni Suef University, Critical Care Medicine, Beni Suef, Egypt. ${ }^{3}$ Faculty of Medicine, Alazhar University, Anaesthesiology, Cairo, Egypt. ${ }^{4}$ Hamad Medical Corporation, Medical Research Center, Biomedical Statistics, Doha, Qatar.

Published: 1 October 2015

\section{Submit your manuscript to a SpringerOpen ${ }^{\circ}$ journal and benefit from:}

- Convenient online submission

- Rigorous peer review

- Immediate publication on acceptance

- Open access: articles freely available online

- High visibility within the field

- Retaining the copyright to your article

Submit your next manuscript at $>$ springeropen.com 